\title{
2.The concept of teaching music step by step
}

\author{
Koncepcia výučby hudby - Krok za krokom
}

DOI: $10.17846 /$ HII.2017.20.185-220

Published by Constantine the Philosopher University in Nitra 2017, No. 20, pp. $185-220$

ISSN: $1338-4872$

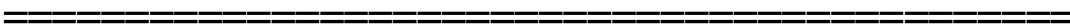

\section{Georg Brunner}

\section{Abstract}

This paper deals with the concept of teaching Music Step by Step, a concept which has been en vogue in the German-speaking countries for over fifteen years. After a short introduction to the concept and its objectives, the neuroscientific insights and learning theories on which it is based, as well as a brief comparison to other concepts of teaching music, the article explores one of the core fields of practice of Music Step by Step: the development of musical abilities. It outlines and discusses different steps and examples of acting and understanding (e. g. audiation, learning with the body, rhythmic and melodic patterns, understanding structures with the help of rhythmical and tonal syllables). Topics such as further dimensions of teaching music, e.g. singing, dancing, listening and describing, editing and inventing, playing instruments are also included. The paper concludes with an overview of first results of smaller empirical studies, which encourage the further development of this concept as well as the expansion of research activities pertaining to a deliberate practice.

Táto štúdia sa zaoberá „po krokovým“ konceptom vyučovania hudby. Tento pojem a princíp je populárny $v$ nemecky hovoriacich krajinách viac ako pätnást' rokov. Po krátkom úvode do konceptu a jeho ciel'ov 
The concept of teaching music step by step

sa koncentrujeme na neurovedecké poznatky a teórie učenia, na ktorých sa koncept zakladá. Stručne porovnávame tento koncept s inými koncepciami výučby hudby. Tento článok sa zaoberá jednou z hlavných oblastí hudobnej praxe- rozvojom hudobných schopností. Popisuje a uvádza rôzne kroky, príklady činnosti a porozumenie (napr. počúvanie, učenie sa telom, rytmické a melodické vzory, pochopenie štruktúry pomocou rytmických a tónových slabík). Témy ako d'alšie dimenzie výučby hudby, napr. spevu, tanca, počúvania a popísania, editácie a vynachádzania, hrania na nástrojoch, sú tiež diskutované v tomto príspevku. $V$ závere článku je uvedený prehlad prvých výsledkov menších empirických štúdií, ktoré podporujú d'alší rozvoj tohto konceptu, ako aj rozširovanie výskumných aktivít vzt'ahujúcich sa $k$ úmyselnej praxi.

\section{Keywords:}

concept, teaching music, objectives and dimensions of music education, acting and understanding, audiation, melodic and rhythmic patterns, solmisation.

koncept, výučba hudby, ciele a rozsah hudobnej výchovy, herectvo a porozumenie, počúvanie, melodické a rytmické vzorce, solmizácia.

\section{1. Primilimnary thoughts on the concept of teaching music step by step}

The teaching concept Music Step by Step has been en vogue in the German-speaking countries for over fifteen years (presented for the first time in Bähr, Gies, Jank \& Nimczik, 2001; for a more recent publication, see "Music step by step 2"; Gies \& Jank, 2015) and continues to heat up discussions about music teaching concepts. Some 
critical-constructive contributions are, for example, included in the commemorative publication from July 2014 for Mechtild Fuchs, one of the most prominent proponents of Music Step by Step in primary schools (cf. Brunner \& Fröhlich, 2014, and in particular the contributions by Jank, Khittl, Stroh, Brunner and Fröhlich; see also Jank \& Stroh, 2006; Geuen \& Orgass, 2007; Gies \& Wallbaum, 2010), as well as the contribution by Hermann J. Kaiser (2016). Before I will discuss examples of Music Step by Step, I would like to start with some preliminary remarks:

What Music Step by Step does not want:

\section{Teach only patterns}

Block out individual needs of children

Impose a rigid corsett

Not encourage creativity

Re-invent music education (cf. Bechtel (Ed.), 2017) What Music Step by Step does want:

Stimulate desire for learning and encourage children (individually) by challenging them

Follow the learning spiral (from one's own actions to increasing skills to developing practical knowledge 
to the concept: the study of music comes before the study about music)

Develop and practice skills step by step

Demand musical quality standards when playing music Allow for diverse approaches (developing a broad musical horizon)

Integrate practices from outside school (cf. Gies \& Jank, 2015, p. 14)

Music Step by Step opposes "patchwork didactics", i.e. teaching "fun" classes without a coherent concept (see Helbling, 2017), by developing learning sequences that are based on insights of neurosciences and learning theories. It draws, for example, on the formation of various forms of mental representation that originate within the areas of connectionism and constructivism (cf. Jank, 2013, p. 66-68; cf. Spychiger, 2015). According to research findings from Jeanne Bamberger, Jerome Bruner, Edwin Gordon and Wilfried Gruhn (as summarised by Gruhn, 2008), these can be described as progressing from figural to formal to symbolic. Simply put, this leads to Edwin Gordon's postulate "sound before sign" (Gordon, 2007, p. 110 , p. 270 ), which considers action as the starting point 
for all musical learning. Skills and abilities are developed via action, and then transferred into concepts. Following John Dewey, Hans Aebli (1983, p. 386) discusses the concept of a learning spiral which essentially applies to all musical development stages and must therefore be given constant consideration in school contexts. Learning by imitation or model-based learning, as well as practice and repetition (deliberate practice; expertise research, Ericsson et al. 1993) play a decisive and fundamental role. Self-guided explorative learning in line with a (moderate) constructivism should also have a firm place in music teaching. Moreover, in recent years, a positive musical self-concept has empirically been proven to be of enormous significance for musical learning (cf. for more detail Spychiger, 2015). These findings are reflected in Music Step by Step, for example, in a sequential approach already familiar to those who have learned how to play a music instrument. The idea is that primarily pupils' musical abilities, but also other competencies, such as listening and describing, moving, creating contexts, editing and inventing, reading and notating as well as guiding others are enhanced through learning steps that are built upon each other. 
Music Step by Step does not, however, re-invent music teaching - on the contrary: In its three fields of practice (1) diverse musical creation, (2) development of musical abilities, and (3) exploration of cultures (cf. Hebling, 2015) -, it draws on and combines existing concepts, such as Active Learning (Rauhe, Reineke \& Ribke, 1975) and Praxial Music Education which was developed in the US (Elliott, 1995) in practice field (1), Talking Rhythm and Solmisation as developed by Zoltan Kodály (1960) or Justine Ward (Combe, 1987) in practice field (2), and Introduction in Music Culture (Antholz, 1972) as well as the production of aesthetic experience (Rolle, 1999) in practice field (3). Clear parallels (as well as differences) can also be found in Elementary Music Pedagogy (Dartsch, 2014, 2016). Elementary Music Pedagogy sees itself as basic music education which does not yet intend a more specialised approach to music, such as playing a music instrument. Therefore, the approach of this method is rather broad: "As a class subject, the Elementary Music Practice is not restricted to a certain age group, although it is particularly relevant for preschool children" (Dartsch, 2014, p. 88). The principles of this approach may therefore 
also be significant for school children, adolescents, and adults.

In 2015, Mechtild Fuchs developed a structural model for elementary school in which she summarises important aspects of music teaching and differentiates them further. This model can be generally applied to music education: 


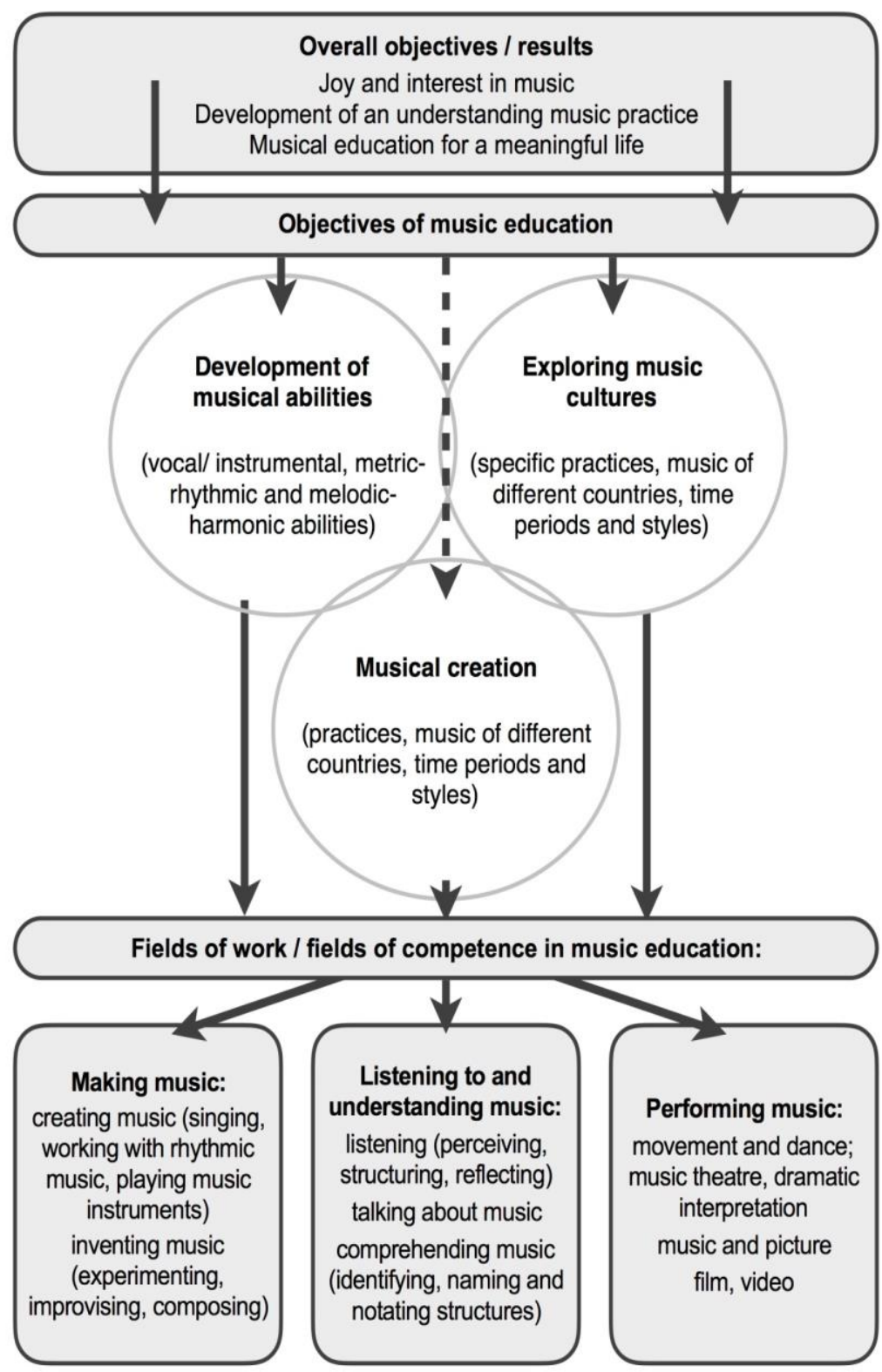


Fig. 1 Structural model of music education. From: Fuchs, M. (Ed.) (2015): Music Didactics Elementary School. Theoretical Foundations and Practical Suggestions, Innsbruck, Esslingen, Bern-Belp Helbling, p. 90.

The hierarchisation of ideas and objectives as well as their operationalisation in different competence fields are clearly recognisable. The outlined objectives unmistakably draw on wording used in Music Step by Step, although the field "Musical Creation" also includes exploring the aesthetic quality of music. The fields of work and competence, in turn, address Dankmar Venus' approaches (first presented in 1969), which determine many educational and school curricula until today. Fuchs' model underlies the assumption that elementary school is the only "music school for all children", regardless of their individual social backgrounds.

In the following, I will demonstrate how teaching in consecutive steps can be applied in an essential area of music education: "Music: acting and understanding". This educational segment relates to all three objectives of music education as described in the above classification and should, according to Jank, be given more than half of 
the available class time in elementary school (Jank, 2013, p. 114).

\subsection{Music: acting and understanding}

In the context of Music Step by Step, "Music: acting and understanding" provides a different view on what, for example, in school text books is called elementary music studies or elementary music theory. In order to ensure sustainability, the following should be achieved:

Connecting theoretical content and musical performance

Understanding the structural foundations of music and recognising them as a meaningful way of communication (cf. Fuchs \& Brunner, 2015, p. 218)

One of the core ambitions is to give meanings to music, which draws on the construction of meaning as formulated by Wilfried Gruhn's: “recognising something to be something" (Gruhn, 2003a, p. 113). This can take place on a semantic level (expressive content: sad, happy, majestic) or on a syntactic level (e.g. parameter, form). Both will be illustrated with the help of examples. 
The syntactic level refers to the rules of tonal relations, tonal orders, intervals, harmonics, metres and rhythms, as well as the formation of small and larger form units. The ability to recognise these elements and work with them actively and creatively requires a music-specific way of thinking, the so called audiation, as developed by the American music psychologist Edwin E. Gordon. Gordon defines audiation as follows:

"Audiation is the foundation of musicianship. It takes place, when we hear and comprehend music for which the sound is no longer or may never have been present. One may audiate when listening to music, performing from notation, playing 'by ear', improvising, composing, or notating music" (The Gordon Institute for Music Learning, 2017).

Anyone who possesses the audiation skills that can and should already be acquired in elementary school, will, according to Mechtild Fuchs, be able to (Fuchs \& Brunner, 2015, p. 219): 
"recognise already familiar melodies and rhythms when listening to music,

compare a melody when listening to music with already known melodies and identify consistencies, similarities, and differences

identify the metre of a rhythm, and the tonality of a melody (for example, with the help of rhythmic and tonal syllables),

combine simple melodies and rhythms to a meaningful unit (for example, by leading a melody to its root, or by continuing a rhythm according to a given metre), imitate and invent melodic and rhythmic patterns, invent songs and rhythmic pieces, recognise familiar melodic and rhythmic patterns in musical notations,

notate and read melodic and rhythmic units, identify formal structures of melodic and rhythmic units and recognise simple forms."

The development of audiation is tied to action and is acquired procedurally (cf. Gruhn, 2003b, p. 97). Via a wide range of practical actions and experiences, children develop an implicit concept of musical structures. These 
form the basis for declarative learning, by which musical experiences are explicitly and cognitively made available via the formation of concepts and rules.

According to Edwin E. Gordon, but also Jerome Bruner, the development takes place in different steps. These steps, however, are not bound to a strict succession and may include loops, returns and new starts. Essentially, they can and must be designed individually. Therefore, they offer an opportunity for differentiated approaches in class ${ }^{189}$. However, it is generally assumed that, even with a non-differentiated approach, individual advancement and development is ensured for all children.

1. Learning with the body:

coordination, vocal training, development of basic musical abilities

2. Identifying structures: introduction of rhythmic and tonal syllables

3. Using symbols:

reading and notating notes

Fig. 2. Step by step model (from: Fuchs, 2010, p. 55; see Süberkrüb, 2003; cf. Jank, 2013, p. 129).

189 It is ultimately the responsibility of the teacher to design tasks that are adequately differentiated and tailored towards individual needs within the group. In selected places, this article provides suggestions for individual learning and differentiation possibilities. 
The following suggested activities should be carried out regularly for about 10 minutes over an extended period of time, always alternating with the aesthetic experience of the whole (singing songs, dancing, listening to music pieces). They help develop an awareness of fundamental musical phenomena. According to Piaget (Montada, 1987) as well as the findings of research on the development of musical abilities, the elements rhythm and melody/harmony are first separated (cf. for a summary overview Gembris, 2005, p. 404: Rhythmic and melodic aspects cannot be grasped simultaneously before the age of seven to eight years; see also Gordon, 2007, pp. 2744).

\subsubsection{Learning with the body}

Metric-rhythmic learning is introduced in various stages, starting with ametric and metric movements (using natural images such as wind, water, fog, fish or gaits of animals such as ponies, elephants, frogs). This can be done individually, in partner work, or in small groups. What follows are metre and weight experience. The learner group listens to pieces in duple and triple metres, such as danceable music in different styles and genres, while key 
aspects are made physically tangible, for example, by standing on tiptoes, then dropping one's weight on the whole foot on stressed beats, tapping along on the thighs while walking, with a clear emphasis on the "one" in the beat. This can be followed by rhythmic pieces without text (e.g. locomotive):

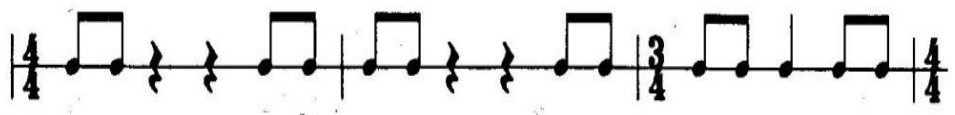
ch b
ch ch ch
ch ka ch ba ch ch ka

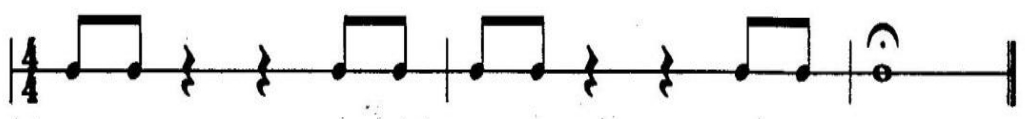

ch $\mathbf{k a}$

ch ch ba

ch ka ch-

Fig. 3. Textless rhythm (from Gordon, Bolton, Hicks \&

Taggart, 1993, p. 129)

The use of spoken verses, poems or Rap, many of which can be found in current song books such as "Mikado" (see Baumann et al., 2001), is also helpful. These can easily be translated into or combined with body percussion pieces. Children may find different individual solutions, for example, in small groups.

A further step is the work with rhythmic patterns. Patterns are recurring building blocks into which music can be 
broken down. They are acquired via imitation (show and copy), non-verbally (using gestures to indicate whether it is the teacher's or learners' turn), by working in a loop (forming a basic metre, for example, by stomping with the feet, adding the rhythmic patterns, for example, by slapping the thighs or tapping a finger on the back of the hand; the basic metre, or macro beat, runs continuously; thus, the music continues for an extended time period) and without notes.
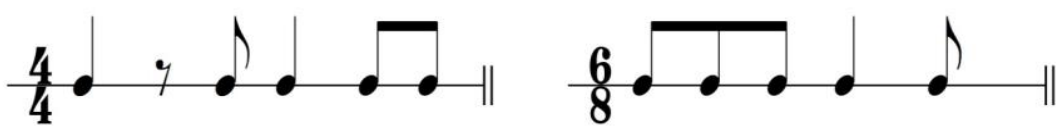

Fig. 4. Rhythmic patterns in duple and triple metres.

Tonal learning (melodic / harmonic) first requires a conscious perception of melody patterns. The instructor teaches the melodies by singing them and having the children sing after them. The children imitate the melody pattern by moving around in the room, or by "conducting" or drawing the course of the melody in the air.

An important component of audiation in tonal music is the focus on the root. Roots can easily be experienced melodically and harmonically: On the melodic level, the 
Gregor Brunner

instructor omits the root note while singing a melody. The children complete the melody with the missing tone; on the harmonic level, songs are accompanied with simple chord root notes, for example, only I and V chords (see Fig. 5). The children indicate the chords with their fingers and show the thumb for I chord, and all five fingers for $\mathrm{V}$ chord.

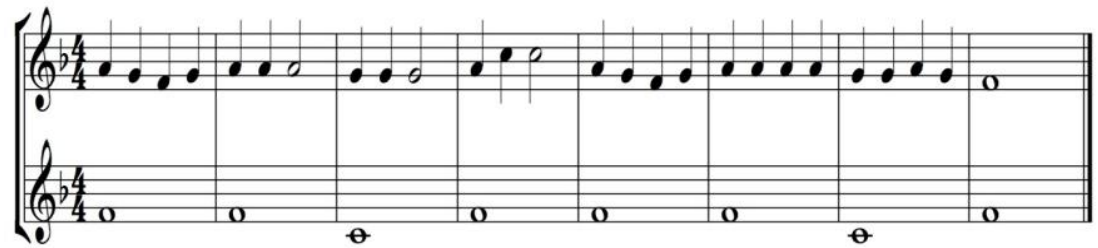

Fig 5. "Mary had a little Lamb" with root chord accompaniment.

The continued work with tonal patterns serves the development of a basic repertoire - many songs can be traced back to similar structures - as well as the improvement of vocal accuracy. Neutral syllables such as ba, na, nu are used for this purpose. The group sits in a circle, and the patterns are introduced individually in small units, with short "audiation breaks" in between. Afterwards, the group sings the entire string of patterns. 


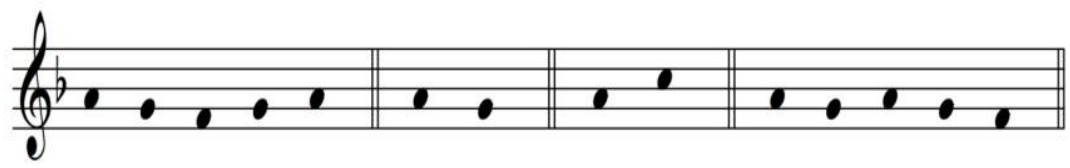

Fig. 6. Melodic patterns of "Mary had a little Lamb".

A basic pillar of Gordon's Music Learning Theory is discrimination learning (cf. Gordon, 2007), by which children learn to distinguish between tonal and metric basic categories. For the distinction between major and minor keys, for example, songs written in a major key are sung in a minor key, and vice versa. As well, in order to learn how to identify duple and triple metres, children perform pieces in duple as well as in triple metres. The instructor points out the differences. Finally, by creating song accompaniments, improvisations and sound stories, the children gather further experience with tone colours (bright-dark, hard-soft, etc.) and (basal) parameters (highlow, loud-soft, fast-slow), as well as patterns via performing with instruments (with everyday objects, selfmade instruments, Orff Instruments, boomwhackers, recorders, ukuleles, etc.). This allows for productive independent activity, and thus provides an opportunity for individual as well as naturally differentiated learning and 
development. Skills and knowledge already acquired can be applied and expanded in small creative "productions".

2.2.2 Undestanding structures with the help of rhythmic and tonal syllables

Music and language only acquire meaning through a certain order and relation of pitches and tone duration, and syllables and words respectively. In order to make these structures clear and comprehensible in music, some cultures and music educational concepts use verbal syllables when working with rhythms. These vary, according to what is to be demonstrated: The syllables Dun - Tschak - Tiki (Reiter, 1998), for example, are used to imitate the sounds of a drum set in popular music. Orff and Keetman prepare improvisations for children by using familiar terms, such as Bir-nen [German for "pears"], Sil-via (Orff \& Keetman, 1950, p. 68 et seq.), the Hungarian music educationalist and composer Zoltan Kodály (1960) suggests using ta and ti for quarter and eighth notes respectively to teach absolute notation, while Edwin E. Gordon (2007) focuses on the tonal differentiation between stressed and unstressed beats by using the syllables $d u$ and dei, as well as $d u-d a-d i$. Music Step by Step draws on Gordon's rhythm language because it best 
accompanies the learning path from metre and rhythm through the entire body via identifying the structures to notation (cf. Fuchs \& Brunner, 2015, p. 230). Likewise, various "verbalisations" of the relations between pitches have been established (for a summary overview Dartsch, 2014, p. 116-123), for example solmisation.

\subsubsection{Working with Rhythm Syllables}

First a brief example of a duple metre with rhythmic syllables according to Gordon:

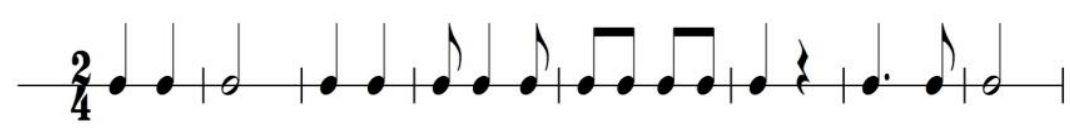

du du du du du du dei dei du dei du dei du du dei du

Fig. 7. Rhythm language according to Gordon.

It is best to start in a circle, introducing the basic pulse (macro beat, for example, by tapping the foot or the heels), introducing small sections (here, for example, two beat patterns) and having the group repeat, while maintaining an uninterrupted musical flow (loop).

Once learners are confident with the patterns, they may transfer them to body percussion and/or music instruments and combine them with spoken words and 
songs. This again provides possibilities for individualisation and differentiation.

In order to promote sustainability and their own inventions, the children should have a basic understanding of the rules: du-dei for a duple metre, du-da-di for a triple metre.

Once the children have a certain basic repertoire of patterns, they can invent their own, based on their individual capabilities and differentiated accordingly (e.g. rondos, stomp "choreographies"). As well, they may expand on what they have learned, for example, by guessing songs and translating patterns into rhythm language (note: no notes are used in all of the above).

\section{2. 4. Working with Tonal Syllables}

The syllables do-re-mi-fa-so-la-ti are used in the so-called relative solmisation, which goes back to Guido of Arezzo (11th century). Do represents the root in major key, la in minor key, regardless of the absolute pitch. The syllables help mark and recognise the function of the tones in a tonal structure: Root notes, intervals, semitones, triads, function tones for root note accompaniment (I degree - IV degree - V degree: do - fa-so). 
First again an example of tonal syllables:

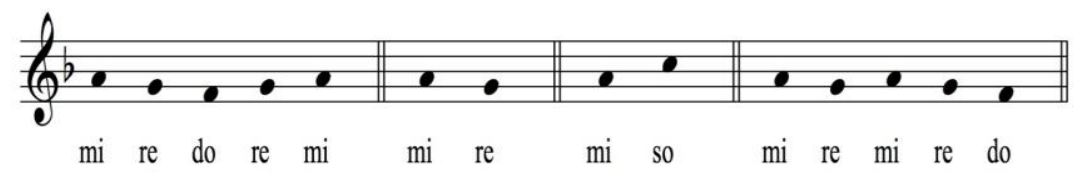

Fig. 8. Example of tonal syllables ("Mary had a little Lamb").

The tonal syllables are acquired in the same way as tonal patterns (without solmisation!). In a further step, the children learn how to read and notate notes: Although not an end in itself, studying musical notation is used as a means to make making music, singing and reflecting easier. Learners notate what they have already experienced musically (see in more detail Fuchs, 2010, p. 175-221).

\section{3. Further dimensions}

A team of authors led by Werner Jank and Stefan Gies (2015) developed the principle of Music Step by Step for secondary schools. They also described further dimensions of music teaching for 13 to 17 year-olds that are in line with teaching in steps that are built upon each other. 


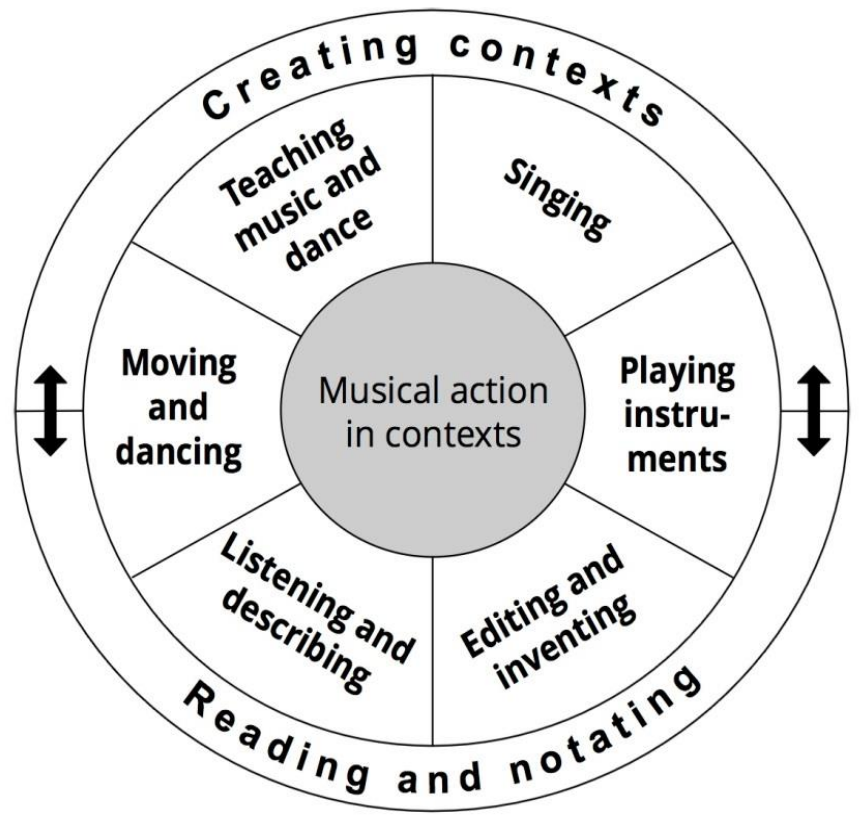

Fig.

9. Dimensions of Music teaching (Gies \& Jank 2015, p. 9)

The dimensions „singing“ and „playing instruments“ form the centre of the practice fields "developing musical abilities" and "diverse ways of playing music". The focus is on a song repertoire that is stylistically diverse, drawn from real life background, with increasing polyphony and possibilities for instrumental accompaniment, as well as regular vocal training. The use of musical instruments in particular (elementary playing techniques on percussion 
instruments, drums, barred percussion instruments, keyboard, electric bass, (e-) guitar; mixed class orchestra) is encouraged. For the perception, feeling, and the musical realisation of metre and rhythm in music, but also for singing and playing instruments, "moving and dancing" with music are indispensable. In this dimension, elementary movement experiences are combined with singing, and the music-related movement repertoire is further enlarged. The dimension "editing and inventing" allows for making music independently and creatively through editing, modifying, improvising and composing music. The ability to "listen to and describe" music is required for competence dimensions. The core of this dimension is both emotional and structural listening, as well as describing the musical effects and the meaning the music has for the people who work with it. The musical abilities mentioned so far are bundled in the dimension "Teaching music and dance" and expanded by the inclusion of the areas "orientation" and "maintaining overview". Taking over a leadership role in musical interaction as well as expanding musical communication skills are also practiced. "Reading and notating" as well as "creating contexts" are considered to play an integrating 
role (shown in the outer ring in the graphic) and are equally important in all dimensions. Working with notes is seen as a tool that is continuously learned, practiced and applied in the six dimensions mentioned above. Musical contexts must always accompany the activities in order to achieve an "understanding" music practice. Therefore, all dimensions include suggestions for deepening certain musical aspects (e.g. comparison of different vocal cultures, acquiring a non-European dance form such as Calypso or Tinikling from the Philippines, Minimal Music, stylistic features of Rock Music, Rap, Chaconne, Aleatoric music, Prokofiev's "Romeo and Juliet" vs. Bernstein's "West Side Story", concertante principle in the baroque and romantic periods, the 19th-century bourgeois concert, dynamics in the course of time) (Gies \& Jank 2015).

\section{4. Empirical research and outlook}

While the concept is well established and widely discussed at the theoretical level (see above), empirical studies on this topic are still at an early stage. Several smaller empirical studies on the core topics development 
of rhythmic and melodic abilities were conducted at the Department of Music at the University of Education in Freiburg (Kapp 2013, Wisser 2013, Brunner 2014, Locher 2016, Ehret 2017). Other than the studies by Locker and Brunner (primary school level), all other studies were conducted on the lower secondary level (10-16 years). The studies by Kapp, Wisser and Ehret were designed as intervention and comparative studies. Kapp and Wisser were not yet able to resort to suitable test methods; however, their results were encouraging in the sense that teaching methods based on Music Step by Step seem to be more suitable for enhancing rhythmic and melodic abilities than traditional music teaching concepts. The study by Ehret shows that teaching according to Music Step by Step leads to the self-assessment of pupils being sensitised. Brunner (2014) demonstrated that teachers who apply Music Step by Step methods have a more positive self-assessment of their teaching success than other teachers. Solmisation and rhythm language have become more prominent in the German-speaking world in recent years (Ansohn 2013/2014, Fuchs 2013) and have, for example, been incorporated in the new 2016 education plans in Baden-Württemberg (http://www.bildungsplaene- 
Gregor Brunner

bw.de/,Lde/Startseite/BP2016BW ALLG/BP2016BW ALL

G GS MUS). On the basis of Music Step by Step, Herbert Schiffels developed an app for tablets (TabDo; http://www.tabdo.net/en/tabdo-3/), which can be used to cover a variety of teaching possibilities for musical abilities, as well as to create new ways of learning, thus working towards a close linking of theory and practice. Locher (2016) was able to demonstrate very positive effects in the fields of "singing and learning songs (practice)", "developing an internal realisation of sound" and "musical notation (theory)". In addition, the app ties in with the media-driven everyday life of the children and thus enhances their media literacy.

\section{tabDo}
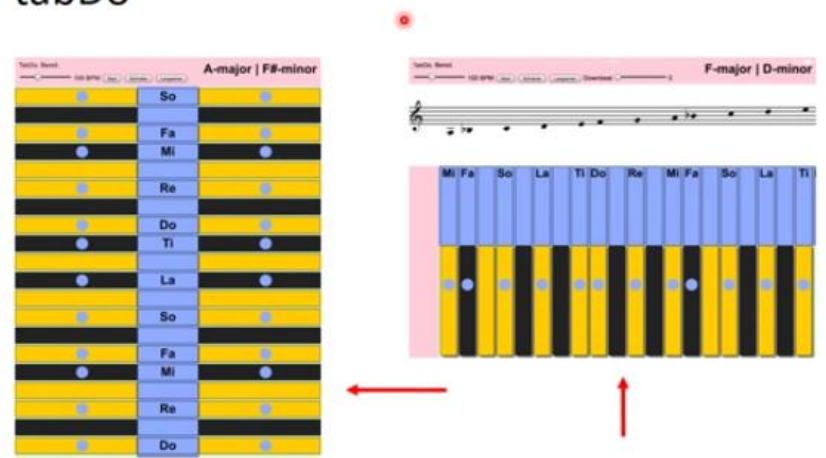

Fig. 10. Example from tabDo

(http://www.tabdo.net/en/videos/) 
Ericsson's expertise approach may be of particular interest for the further development of Music Step by Step, especially with regards to the expansion of practical skills and abilities (Ericsson et al., 1993). Deliberate Practice plays a key role. It involves structured - guided - activities with the objective of improving performance (long - term learning objectives). The efficient development of skills takes place in the upper, but not the maximum level of performance expectations, i.e. time and again the performance limits of learners are nearly reached, which leads to permanent adaptivity (Platz \& al. 2014). It is important that the instructor acts as a guiding expert who defines specific short-term learning goals that are built upon each other, differentiates them further, according to varying abilities in the group, and carries them out in a controlled and goal-oriented manner (no pure mechanics), combining a kind of monitoring (conscious, supervised practice) with constant feedback. The teacher provides support for self-regulated learning. This requires high motivation, concentration and effort from learners. Essentially, a philosophy of training during class should be developed: training as integral part of classroom 
instruction. Research should endeavour to obtain more knowledge on factors that influence the degree of difficulty in class (e.g. test theoretical task analysis) in order to evaluate and optimise the already well elaborated methods of Music Step by Step. This should be based on expert observation (micro analysis) of practice behaviour and further adaptation of the expert concepts according to specific requirements of children's learning.

\section{References:}

AEBLI, Hans. 1983. Zwölf Grundformen des Lehrens. Eine Allgemeine Didaktik auf psychologischer Grundlage. Stuttgart: Klett-Cotta, 1983. 409 p. ISBN 978-3-60893044-3.

ANSOHN, Meinrad. 2013. Beiträge zur Solmisation heute. In AfS-Magazin 2013, no. 36, p. 4.

ANTHOLZ, Heinz. 1972. Unterricht in Musik. Düsseldorf: Schwann, 1972. 252 p. ISBN 3789500895.

BÄHR, Johannes, GIES, Stefan, JANK, Werner \&NIMCZIK, Ortwin. 2001. Zukunft des Musikunterrichts Musikunterricht der Zukunft. In K. Pilnitz, B. Schüssler, J. Terhag \& M. Ansohn (Ed.), Musikunterricht heute Bd. 4. Musik in den Medien - Medien in der Musik. Oldershausen: Lugert, 2001. ISBN 3-89760-203-2, pp. 230-246. 
BAUMANN, Hannelore \& MELCHER-SCHMITT, Renate. 2001. Mikado. Unser Liederbuch für die Grundschule. Leipzig, Stuttgart, Düsseldorf: Klett, 2001. 159p. ISBN: 978-3121727605.

BECHTEL, Dirk. 2017. Wiki Musikpädagogik. Artikel Aufbauender Musikunterricht. Available online at: http://www.dirk-

bechtel.de/wiki/index.php?title=Aufbauender_Musikunterri cht [11.01.2017].

BRUNNER, Georg. \& FRÖHLICH, Michael. (Ed.) 2014. Impulse zur Musikdidaktik. Festschrift für Mechtild Fuchs. Innsbruck, Esslingen, Bern-Belp: Helbling, 2014. 456p.

ISBN 978-3-99035-216-8.

BRUNNER, Georg. (2014) Diagnose- und Förderstrategien von Lehrkräften im Musikunterricht der Grundschule zur Qualitätsverbesserung des Singens. In G. Brunner \& M. Fröhlich (Ed.). Impulse der Musikdidaktik. Festschrift für Mechtild Fuchs. Innsbruck/Esslingen: Helbling, 2014. ISBN 978-3-99035-216-8. pp. 231-270.

COMBE, Pierre 1987. Justine Ward and Solesmes. Washington: Catholic University of America. 1987. 410p.

DARTSCH, Michael. 2014. Musik lernen - Musik unterrichten. Eine Einführung in die Musikpädagogik. Wiesbaden u. a.: Breitkopf \& Härtel. 248 p. ISBN 978-3 7651-0399-5.

EHRET, Marie-Luise. 2017. Kann das Konzept des Aufbauenden Musikunterrichts im Vergleich zu 
Gregor Brunner

Musikunterricht ohne spezielle Intervention das musikbezogene Kompetenzerleben bei SuS im Musikunterricht der Realschule steigern? - Eine empirische Studie. Freiburg (Academic Thesis, unpublished). 2017.

ELLIOTT, David J. 1995. Music Matters. A New Philosophy of Music Education. New York, Oxford: University Press, 1995. 400 p. ISBN 978-0195091717.

ERICSSON, K. Anders, KRAMPE, Ralf Th. \& TESCHROMER, Clemens. 1993. The role of deliberate practice in the acquisition of expert performance. In Psychological Review, 1993, 100(3), pp. 363-406.

FUCHS, Mechtild. \& BRUNNER, Georg. 2015. Handeln und begreifen: Aufbau musikalischer Fähigkeiten. In M. Fuchs (Ed. ), Musikdidaktik Grundschule. Theoretische Grundlagen und Praxisvorschläge. Innsbruck, Esslingen, Bern-Belp: Helbling, 2015. ISBN 978-3-86227-210-5. pp. 218-252.

FUCHS, Mechtild. 2010. Musik in der Grundschule neu denken - neu gestalten. Theorie und Praxis eines aufbauenden Musikunterrichts. Innsbruck, Esslingen, Bern-Belp: Helbling, 2010. 280 p. ISBN 978-3-86227-0576.

FUCHS, Mechtild. 2013. So-Mi. Zur Rückkehr der Solmisation in den deutschen Musikunterricht. In AFSMagazin 2013, no. 36, pp. 7-14. 
The concept of teaching music step by step

FUCHS, Mechtild. 2015. Musikdidaktik Grundschule. Theoretische Grundlagen und Praxisvorschläge. Innsbruck, Esslingen, Bern-Belp: Helbling, 2015. 391 p. ISBN978-3-86227-210-5.

GEMBRIS, Heiner. 2005. Die Entwicklung musikalischerFähigkeiten. In $\mathrm{H}$. de la Motte-Haber \& G. Rötter (Ed.).Musikpsychologie. Handbuch der SystematischenMusikwissenschaft: Bd. 3. Laaber: Laaber, 2005, ISBN978-3-89007-564-8. pp. 394-456.

GEUEN, Heinz \& ORGASS, Stefan. 2007. Partizipation Relevanz - Kontinuität. Musikalische Bildung und Kompetenzentwicklung in musikdidaktischer Perspektive,Herzogenrath: Shaker Verlag, 2007.131p, ISBN 978-3-8322-6559-5.

GIES, Stefan. \& JANK, Werner. 2015. Music step by step 2. Aufbauender Musikunterricht ab Klasse 7. Lehrerband. Innsbruck, Esslingen, Bern-Belp: Helbling, 2015.304 p. ISBN 978-3-86227-204-4.

GIES, Stefan \& WALLBAUM, Christopher. 2010. Aufbauender Musikunterricht vs. Musikpraxen erfahren? In Georg Maas und Jürgen Terhag (Hg.), Zwischen Rockklassikern und Eintagsfliegen. 50 Jahre populäre Musik in der Schule. Oldershausen: Lugert (8),2010, ISBN 978-3-89760-367-7. pp. 83-91.

GORDON, Edwin e al. 1993. Experimental Songs and Chants Without Words. Chicago: GIA, 1993. 100 p, PPN 075137178. GORDON, Edwin. 2007. Learning Sequences in Music. A Contemporary Music Learning Theory. Chicago: GIA, 2007. 448 p, ISBN 978-1-57999-688-8. 
Gregor Brunner

GRUHN, Wilfried. 2003a. Lernziel Musik. Hildesheim, Zürich, New York: Olms, 2003a. 153 p, ISBN 3-48711952-8.

GRUHN, Wilfried. 2003b. Kinder brauchen Musik. Musikalität bei kleinen Kindern entfalten und fördern. Weinheim: Beltz, 2003b. 141 p. ISBN 978-3-407-22867-3.

GRUHN, Wilfried. 2008. Der Musikverstand. Neurobiologische Grundlangen des musikalischen Denkens, Hörens und Lernens. Göttingen: Olms, 2008. 271 p. ISBN 978-3-487-13668-4.

Helbling Verlag GmbH. 2017. Available online at: www.aufbauender-musikunterricht.de [11.01.2017].

JANK, Werner. 2013. Musikdidaktik. Praxishandbuch für die Sekundarstufe I und II. Berlin: Cornelsen Scriptor, 2013.256 p. ISBN 978-3-589-03939-5.

JANK, Werner \& STROH, Wolfgang M. 2006. Aufbauender Musikunterricht - Königsweg oder Sackgasse? In Wolfgang Pfeiffer und Jürgen Terhag (Ed): Schülerorientierter Musikunterricht - Wunsch und Wirklichkeit. Oldershausen: Lugert, 2006. ISBN 3-89760 289-X. pp. 52-64.

KAISER, Hermann J. 2016. Aufbauender Musikunterricht. In Andreas Lehmann-Wermser (Ed.).Musikdidaktische Konzeptionen. Ein Studienbuch.(= musikpädagogik im fokus Bd. 3) Augsburg: Wißner, 2016. ISBN 978-3-95786023-1. pp. 65-82. 
KAPP, Linda. 2013. Aufbauender Musikunterricht (AMU) in der Realschule - eine empirische Studie zur Entwicklung rhythmischer Fähigkeiten. Freiburg (Academic Thesis, unpublished).

KODALY, Zoltan. 1960. 333 olvasógyakorlat. Bevezetó a magyar népzenébe. Budapest: Editio Musica, 1960. 61 p.

LOCHER, Julia. 2016. TAbDo - eine Chance für die Umsetzung der Solmisation im Musikunterricht? Befunde einer empirischen Studie an zwei Schulen im Raum Freiburg Freiburg (Academic Thesis, unpublished).

MONTADA, Leo .1987. Die geistige Entwicklung aus der Sicht Jean Piagets. In R. Oerter \& L. Montada (Ed.), Entwicklungspsychologie. Weinheim: Beltz-Verlag, Psychologie-Verlags-Union, 1987. ISBN 3-621-27017-5. pp. 413-462.

NANDAGOPAL, Kiruthiga \& ERICSSON, K. Anders. 2012.. Enhancing students' performance in traditional education: Implications from the expert performance approach and deliberate practice. In K. R. Harris, S. Graham, and T. Urdan (Ed.), APA Educational Psychology Handbook: Vol. 1. Theories, Constructs, and Critical Issues. Washington, D. C.: American Psychological Association, 2012. ISBN 978-1-4338-0996-5. pp. 257293.

ORFF, Carl \& KEETMAN, Gunhild. 1950. Orff-Schulwerk, Bd. I. Mainz: Schott, 1950. 66 p.

PLATZ, Friedrich e al. 2014. The influence of deliberate practice on musical achievement: a meta-analysis. In 
Gregor Brunner

Frontiers in Psychology, 2014, 5(646). doi:10.3389/fpsyg.2014.00646, 2014.

RAUHE, Hermann, REINEKE, Hans-Peter \& RIBKE, Wilfried. 1975. Hören und Verstehen. Theorie und Praxis handlungsorientierten Musikunterrichts. München: Kösel, 1975. 246 p. ISBN 978-3-466-30136-2.

REITER, Gerhard. 1998. Body Percussion 1. Rhythmisches Basistraining \& Percussion-Arrangements. Innsbruck: Helbling, 1998. 120 p. ISBN 3-85061-095-0.

ROLLE, Christian. 1999. Musikalisch-ästhetische Bildung. Über die Bedeutung ästhetischer Erfahrung fürmusikalische Bildungsprozesse. Perspektiven zur Musikpädagogik und Musikwissenschaft: Bd. 24. Kassel:Bosse, 1999. 197 p. ISBN 978-3-7649-2492-8.

SPYCHIGER, Maria. 2015. Lernpsychologische Perspektiven für eine grundschulspezifische Musik didaktik. In M. Fuchs (Hrsg.), Musik didaktik Grundschule. Theoretische Grundlagen und Praxis vorschläge. Innsbruck, Esslingen, Bern-Belp:Helbling, 2015. ISBN9783-86227-210-5. pp. 50-71.

SÜBERKRÜB, Almuth. 2003. Denken in Musik: Audiation. In mip Journal 2003, (7), pp. 6-13.

The Gordon Institute for Music Learning.2017. Available online at: http://giml.org/mlt/audiation [11.01.2017].

VENUS, Dankmar. 1969. Unterweisung im Musikhören. Wilhelmshaven: Noetzel, 1969. 198 p. ISBN 978-3-79590414-2. 
The concept of teaching music step by step

WISSER, Sarah. 2013. Aufbauender Musikunterricht in der Sekundarstufe I. Eine empirische Studie zur Entwicklung melodischer Fähigkeiten. Freiburg (Academic Thesis, unpublished), 2013.

\section{Contact information:}

Gerg Brunner, Prof. Dr.

Pädagogische Hochschule Freiburg

(University of Education),

Instituute of Music

Email:georg.brunner@ph-freiburg.de 